\title{
THE ANALYSIS OF PUBLIC SERVICE QUALITY TO THE COMMUNITY IN THE WONOTIRTO SUB-DISTRICT OFFICE OF BLITAR REGENCY
}

\author{
Sulistyo Anjarwati \\ Program Studi Administrasi Negara, Universitas Islam Balitar \\ Email : sulistyoanjar91@gmail.com
}

\begin{abstract}
Service to the community is the main goal of the government which is impossible to cause because the government must provide the best for the community, because it has made an agreement with the government, it is fitting for the government to find the best solution for problems related to needs. to prioritize the quality of community services for offices in Wonotirto sub-district. The research method used in this study is a quantitative method. The norm assessment is also conducted to see the high, medium or low of each dimension of service quality and after the data has been processed with the help of SPSS 16.00 computer for windows. The results of this study answer 75 respondents to the quality of community service in Wonotirto Sub-District Blitar Regency is good (seen in the average respondent responding well to each notification); The average score of the largest average percentage is $61.9 \%-80 \%$.
\end{abstract}

Keywords: Quality, Public Services, Society,

\section{INTRODUCTION}

Government is an organization in realizing welfare, in realizing good and ideal governance, and improving the performance of official government and public quality. The main purpose of forming a government is to maintain a system in which the community can live life naturally. Modern government is essentially a service to the community and has the duty to serve the community, creating conditions that allow each member of the community to develop their abilities and creativity to achieve the progress together.

Government Science is a public work unit, the government works to fulfill activities (producing, transferring, distributing) and protecting community needs, interests and demands of those governed as consumers and sovereign, public services and civil services, in government relations (Ndraha, 2000: 7).

The 1945 Constitution mandates that a State has an obligation to serve every citizen and to fulfill their basic rights and needs within the framework of public 
services (Society). The quality of service activities for the community to fulfill these obligations, the government establish the Public Services law to provide legal security in the relationship between the community and the organizers in public services as well as reinforce the fulfillment of public services for citizens.

The Public Service Act or Law Number 25 of 2009 concerning Public Services is a law that regulates the principles of good governance which are those that run the effectiveness of government functions. Effective public service activities carried out by government or corporations can strengthen democracy and human rights, promote economic prosperity, social cohesion, reduce poverty, improve environmental protection, be wise in the use of natural resources, deepen trust in government and public administration. Public service is an activity or series of activities in order to fulfill service needs in accordance with the laws and regulations for every citizen and resident for the goods, services, and / or administrative services provided by public service providers.

One of the example public service in Wonotirto District is public services. One of the public servis in the sub-district office is the making of a Family Card which is a family identity card that contains data about the name, family relationships and family member identity. Every family only has one family and each resident is recorded in only one household. The Family Card is published and signed by the Head of the institution given to residents of Indonesian Citizens and Foreigners who have permanent residence permits, and changes in the family structure on the family card must be reported to the institution not more than 30 days from the changes.

Problems that occur with the vast area of Blitar Regency are still many people or family heads in Wonotirto District who do not have a family card as their identity. The reason for making it is still complicated from one table to another. So as to reduce the intention of the head of the family not to have and make a family card, there will also be a lack of understanding of the community regarding the requirements and procedures for making a family card, which must be accompanied by a local RT / RW to the village by filling out various forms which provides until the end in the District that sees the completeness until the 
data goes to the institution then processed. This is quite time consuming in the process of making a family card.

Various problems in the process of public service to the community that reflect community dissatisfaction with the government's public services. The problem of public services provided by government officials is the main complaint of the community. Because of the process of servis is often not in accordance with established procedures. Even though there is a minimum service standard (SPM) in every government agency. This is the problem of implementing government organizers. Therefore, it is necessary to have a public management strategy in servants to the community so that they can provide satisfaction so that they will get a good image (Huda \& Martanti, 2018).

The things that people often complain about the proces of public service, especially regarding the problem of making family cards. The occurrence of Discrimination in Providing Services is not secret, because this is common and often occurs in the field. Many communities have become victims of discrimination in public services. This discrimination can be related to kinship, friendship, family, ethnicity, social status and so on.

We can see how government apparatus are still not fear in the field of giving services. For example, in providing services in making of family card, different attitudes and procedures for the government apparatus to accept people who wearing ties is different. For people with ties, the officers are usually very friendly, but if an ordinary person changes his face, he can turn 180 degrees.

The occurrence of Extortion, In providing public services, the officers usually offer two ways to the community, namely fast and slow ways. This quick way is what we mean by the extortion process. Usually this fast method requires a high cost. In this case the victims are people who do not have money or the poor.

There Is No Certainty, In providing public services also, government agencies usually do not provide certainty, both from the time and costs needed. With this uncertainty, government officials often conduct Community Service Programs. This is an opportunity for government officials to increase income in a bad way.

Besides that, this could have been caused by an error in the lack of support from government procurement facilities or work facilities. As a result of the above matters, it 
must be acknowledged slowly and will reduce the level of public trust in the ability and performance of the government. To explain this, the government must be more responsive and accountable in order to provide excellent service and to satisfy the community.

Definition Quality of service is an effort to fulfill the needs and desires of customers and the accuracy of delivery to offset customer expectations. So that it can be concluded that service quality is a statement about attitudes, relationships that result from a comparison between expectations (expectations) and performance (results) (Tjiptono, 2011: 164)

From the descriptions above, researchers feel the quality of service in Wonotirto Subdistrict is a review of researchers in developmental sciences as well as for the science of government. Therefore the researcher conducted the research title, "The Analysis of the Quality of Public Services to Communities in Wonotirto District, Blitar Regency".

\section{RESEARCH METHOD}

The research method used in this research is descriptive research method with a quantitative approach. Descriptive research method with a quantitative approach is used if it aims to describe or explain events or an event that occurs at present in the form of numbers that are meaningful (Sudjana, 1997: 53). The description means to collect data as much as possible about the analysis of the quality of public services to the people in the Wonotirto District of Blitar Regency.

The purpose of descriptive research with this quantitative approach is to explain a situation to be investigated and supported by library studies so it further strengthens the analysis of researchers in making conclusions. Where the results of the study are obtained from the results of the calculation of variable indicators of research then presented in writing by the researcher. By taking 70 samples randomly when the study occurred.

This research is to analyze the data from the written test using the assessment formula as follows: 
$N P=\frac{R}{S M} \times 100 \%$

Keterangan:

$\mathrm{NP} \quad=$ is the percent value sought or expected in the study

$\mathrm{R}=$ is the raw value obtained by respondents in the study

$\mathrm{SM}=$ is the ideal maximum value of the research test

$100 \%=$ is a fixed percent number

Tabel 1, Interpretation of the quality of public services

\begin{tabular}{|c|c|c|}
\hline No. & Prosentase & Kriteria \\
\hline 1. & $81 \%-100 \%$ & Very good \\
2. & $61 \%-80 \%$ & Good \\
3. & $41 \%-60 \%$ & Fair \\
4. & $21 \%-40 \%$ & Poor \\
5. & $0 \%-20 \%$ & Bad \\
\hline
\end{tabular}

\section{DISCUSSION}

\section{THE ANALYSIS OF STATISTICS, HIGHEST DESCRIPTION IN EACH OF THE QUALITY OF VARIABLE SERVICES}

Table 2. Frequencies of The Highest Respondents' Responses in Each Item of Service Quality Variables

\begin{tabular}{|c|c|c|l|}
\hline No. Item & $\begin{array}{c}\text { \% } \\
\text { Highest }\end{array}$ & Mean & \multicolumn{1}{c|}{$\begin{array}{c}\text { Response } \\
\text { (Shows the majority of respondents) }\end{array}$} \\
\hline Tangible (Phisical Evidence) & \multicolumn{2}{|c|}{} \\
\hline 1 & 62,7 & 3.5733 & $\begin{array}{l}\text { Respondents stated good both the facilities and } \\
\text { the physical condition of the District office } \\
\text { building. }\end{array}$ \\
\hline 3 & 76 & 3.7867 & $\begin{array}{l}\text { Respondents stated good related to comfort } \\
\text { place, cleanliness and neatness of the district } \\
\text { service room. }\end{array}$ \\
\hline 4 & 49,3 & 3.4267 & $\begin{array}{l}\text { Respondents stated good related to the Loket } \\
\text { arrangement at the District Office. }\end{array}$ \\
\hline $\begin{array}{l}\text { Respondents stated fair related the condition } \\
\text { and adequacy of office equipment and } \\
\text { equipment to facilitate services (such as } \\
\text { computers, typewriters, telephones, faxes, etc.). }\end{array}$ \\
\hline
\end{tabular}




\begin{tabular}{|c|c|c|c|}
\hline 5 & 90,7 & 3.9600 & $\begin{array}{l}\text { Respondents stated good both the ease of } \\
\text { filling and the use of application forms or public } \\
\text { services. }\end{array}$ \\
\hline \multicolumn{4}{|c|}{ Realibility (Skill) } \\
\hline 6 & 66,7 & 3.7867 & $\begin{array}{l}\text { Respondents stated good related to the abilty of } \\
\text { officers to fulfill the timeliness in the } \\
\text { completion of public services which is } \\
\text { promised. }\end{array}$ \\
\hline 7 & 93,3 & 4.0400 & $\begin{array}{l}\text { Respondents stated good on the ability of } \\
\text { officers to provide public services that are fast, } \\
\text { easy and not complicated. }\end{array}$ \\
\hline 8 & 89,3 & 3.9733 & $\begin{array}{l}\text { Respondents stated good on the attitude of } \\
\text { officers in providing information and } \\
\text { information about the management of public } \\
\text { services that are fast, easy, and not complicated. }\end{array}$ \\
\hline 9 & 92 & 3.9200 & $\begin{array}{l}\text { Respondents stated good at applying the } \\
\text { accuracy of office hours and public service } \\
\text { schedules. }\end{array}$ \\
\hline 10 & 93,3 & 3.9333 & $\begin{array}{l}\text { Respondents stated good on the suitability } \\
\text { between the specified public services. }\end{array}$ \\
\hline \multicolumn{4}{|c|}{ Responsiveness } \\
\hline 11 & 89,3 & 3.9733 & $\begin{array}{l}\text { Respondents stated good on the ability of sub- } \\
\text { district officials to be quick to respond the } \\
\text { public complaints from users of public services. }\end{array}$ \\
\hline 12 & 97,3 & 3.9733 & $\begin{array}{l}\text { Respondents stated good to the immediate } \\
\text { action of the sub-district officers in resolving } \\
\text { problems or providing assistance to the public } \\
\text { requesting public services. }\end{array}$ \\
\hline 13 & 97,3 & 4.0267 & $\begin{array}{l}\text { Respondents stated good on the ability of } \\
\text { officers to provide clear and easy-to-understand } \\
\text { information about public services. }\end{array}$ \\
\hline \multicolumn{4}{|c|}{ Assurance } \\
\hline 14 & 80 & 3.8000 & $\begin{array}{l}\text { Respondents stated good on the suitability } \\
\text { between costs incurred with the costs set. }\end{array}$ \\
\hline 15 & 86,7 & 3.8933 & $\begin{array}{l}\text { Respondents stated good on the mechanism or } \\
\text { path of complaints, if the users have problems } \\
\text { in service. }\end{array}$ \\
\hline 16 & 98,7 & 4.0133 & $\begin{array}{l}\text { Respondents stated good on the ability to } \\
\text { provide services thoroughly and complete. }\end{array}$ \\
\hline \multicolumn{4}{|c|}{ Emphaty } \\
\hline 17 & 93,3 & 3.9600 & Respondents expressed good to the attention of \\
\hline
\end{tabular}




\begin{tabular}{|c|c|c|l|}
\hline & & & officers specifically to the customer community. \\
\hline 18 & 90,7 & 3.9333 & $\begin{array}{l}\text { Respondents stated good at listening carefully } \\
\text { to people's complaints. }\end{array}$ \\
\hline 19 & 96 & 3.9867 & $\begin{array}{l}\text { Respondents stated good at ease in submitting } \\
\text { complaints. }\end{array}$ \\
\hline
\end{tabular}

Based on table 2, it is known that the responses of 75 respondents to each variable dimension of the quality of public service services in the Wonotirto Subdistrict, Blitar Regency, which are in the highest category are number questions as follows:

1. Tangible dimensions (physical evidence), the item number 5, namely $90.7 \%$ of respondents stated both the ease of filling and the use of application forms or public services.

2. Realibility dimensions, the items number 7 and 10 , that is $93.3 \%$ of respondents stated well on the ability of officers to provide public services that are fast easy and uncomplicated the ability of officers to provide public services that are fast easy and not complicated and the compatibility between public services as specified.

3. Responsiveness dimension, the items number 12 and 13, that is $97.3 \%$ of respondents stated both on the immediate action of sub-district officers in solving problems or providing assistance to the applicant community for public services and the ability of officers to provide clear and easy-tounderstand information about public service management is included in the respondent's category of responses to high variables.

4. Assurance dimension (guarantees or beliefs), the item number 16, that is $98.7 \%$ of respondents stated well on the ability to provide services thoroughly and complete.

5. The assurance dimension, the item number 19 , that is $96 \%$ of respondents stated good at ease in submitting complaints.

Based on the data above, it can be concluded that the overall response of 75 respondents to the variable quality of public services in Wonotirto District, Blitar 
Regency is known that the assurance dimension (assurance or confidence) is in the category of respondents' responses to the highest variable. While the dimensions of tangible included in the category of respondents' responses to the lowest variables are mainly indicated in the condition and adequacy of office equipment and equipment to facilitate services (such as computers, typewriters, telephones, faxes, etc.) assessed by respondents as poor.

\section{STATISTICS ANALYSIS DESCRIPTIVE LEVEL OF EACH DIMENSION OF SERVICE QUALITY}

The norm calculation is done to see the level of each variable item so that it is known whether the level is high; medium; or low. The scores obtained are then interpreted and classified. The classification is the following table:

Tabel 3, Norma Skor

\begin{tabular}{|c|c|}
\hline Klasifikasi & Skor \\
\hline High & $(\bar{X}+1 S D) \leq X$ \\
\hline Medium & $(\bar{X}-1 S D) \leq X<(\bar{X}+1 S D)$ \\
\hline Low & $X-\langle(\bar{X}-1 S D)$ \\
\hline
\end{tabular}

The percentage formula is used to calculate the percentage of subjects included in the high category; medium; and low as follows:

$$
N P=\frac{R}{S M} \times 100 \%
$$

After the data is processed with SPSS 16.00 for windows computers, it is known that the str deviation of each dimension of the analysis variable is the quality of public services in Wonotirto District, Blitar Regency as in the table below: 
Tabel 4, Mean and Str Deviation of each Dimention of Variable

\begin{tabular}{|c|c|c|c|c|c|c|}
\hline & & Tangible & Realibility & Responsiveness & Assurance & Emphaty \\
\hline N & Valid & 75 & 75 & 75 & 75 & 75 \\
\hline & Missing & 0 & 0 & 0 & 0 & \\
\hline & & 34.2667 & 19.6533 & 11.9733 & 11.7067 & 11.8800 \\
\hline & Deviation & 23.85957 & 1.27865 & .46421 & .63189 & .49210 \\
\hline
\end{tabular}

Based on table 4 the results of the research conducted on 75 respondents of descriptive analysis carried out with SPSS 16.0 for windows obtained the average and sr deviation of each dimension of the research variable as follows:

1. Tangible dimension obtained scores by the average or $M=34.2667$ and str deviasi or $\mathrm{SD}=23.85957$;

2. Realibility dimension obtained scores by the average or $M=19.6533$ and str deviasi or $\mathrm{SD}=1.27865$;

3. Responsiveness dimension obtained scores by the average or $\mathrm{M}=11.9733$ and str deviasi oru $\mathrm{SD}=0.46421$;

4. Assurance dimension obtained the scores by the average or $M=11.7067$ and str deviasi or $\mathrm{SD}=0.63189$;

5. Emphaty dimension obtained scores by the average or $\mathrm{M}=11.8800$ and str deviasi or $\mathrm{SD}=0.49210$.

Furthermore, referring to the data is categorized as high; medium; and low as below:

Tabel 5, Percentage of tangible dimension level

\begin{tabular}{|c|l|r|r|}
\hline Klasifikasi & \multicolumn{1}{|c|}{ Interval } & Frekuensi & Proporsi \% \\
\hline Tinggi & $58,12627 \leq X$ & 55 & 73,33 \\
\hline Sedang & $10,40713 \leq X\langle 58,12627$ & 20 & 26,67 \\
\hline Rendah & $X\langle 10,40713$ & 0 & 0 \\
\hline \multicolumn{2}{|c|}{$\sum$} & 75 & 100,0 \\
\hline
\end{tabular}

Based on table 5, it is known that out of 75 respondents there are $73.33 \%$ level dimensions of tangible (physical evidence) in the high category; 26.67\% of the dimensions of tangible (physical evidence) are in the medium category; and $0 \%$ of the dimensions of tangible (physical evidence) are in the low category. 
Graphically it can be described as follows:

Tabel 6, Precentage of Realibility dimension level

\begin{tabular}{|c|l|r|r|}
\hline Klasifikasi & \multicolumn{1}{|c|}{ Interval } & Frekuensi & Proporsi \% \\
\hline Tinggi & $20,93195 \leq X$ & 53 & 70,67 \\
\hline Sedang & $18,37465 \leq X<20,93195$ & 18 & 24 \\
\hline Rendah & $X\langle 18,37465$ & 4 & 5,33 \\
\hline \multicolumn{2}{|c|}{$\sum$} & 75 & 100,0 \\
\hline
\end{tabular}

Based on table 6 it is known that out of 75 respondents there are $70.76 \%$ level of realibility in the high category; $24 \%$ realibility dimension is in the medium category; and 5.33\% realibility dimension (low) is in the low category. Graphically it can be described as follows:

Tabel 7, Precentage of Responsiveness dimension level

\begin{tabular}{|l|l|r|r|}
\hline Klasifikasi & Interval & Frekuensi & Proporsi \% \\
\hline Tinggi & $12,43751 \leq X$ & 68 & 90,67 \\
\hline Sedang & $11,50909 \leq X\langle 12,43751$ & 7 & 9,33 \\
\hline Rendah & $X\langle 11,50909$ & 0 & 0 \\
\hline & $\sum$ & 75 & 100,0 \\
\hline
\end{tabular}

Based on table 7 it is known that out of 75 respondents there are $90.67 \%$ level of responsiveness (sensitivity) in the high category; 9.33\% level of responsiveness (sensitivity) in the medium category; and $0 \%$ the level of responsiveness (sensitivity) is in the low category. Graphically it can be described as follows:

Tabel 8, Precentage of Assurance dimension level

\begin{tabular}{|l|l|r|r|}
\hline \multicolumn{1}{|c|}{ Klasifikasi } & \multicolumn{1}{|c|}{ Interval } & Frekuensi & Proporsi \% \\
\hline Tinggi & $12,33859 \leq X$ & 56 & 74,66 \\
\hline Sedang & $11,07481 \leq X\langle 12,33859$ & 14 & 18,67 \\
\hline Rendah & $X\langle 11,07481$ & 5 & 6,67 \\
\hline \multicolumn{2}{|l|}{$\sum$} & 75 & 100,0 \\
\hline
\end{tabular}

Based on table 8 it is known that out of 75 respondents there are $74.66 \%$ assurance level (assurance or confidence) in the high category; 18.67\% assurance (assurance or confidence) level is in the medium category; and 6.67\% of the assurance (assurance or confidence) level is in the low category. Graphically it can be described as follows: 
Tabel 9, Precentage of Emphaty dimension level

\begin{tabular}{|c|l|r|r|}
\hline Klasifikasi & \multicolumn{1}{|c|}{ Interval } & Frekuensi & Proporsi \% \\
\hline Tinggi & $12,3721 \leq X$ & 64 & 85,33 \\
\hline Sedang & $11,3879 \leq X\langle 12,3721$ & 10 & 13,33 \\
\hline Rendah & $X\langle 11,3879$ & 1 & 1,33 \\
\hline \multicolumn{2}{|c|}{$\sum$} & 75 & 100,0 \\
\hline
\end{tabular}

Based on table 9 it is known that out of 75 respondents there are $85.33 \%$ level of emphaty dimension in the high category; $13.33 \%$ level of empathy is in the medium category; and $1.33 \%$ level of empathy in the low category.

overall it can be concluded that the responses of 75 respondents to the level of quality of public services in Wonotirto Subdistrict, Blitar Regency are good (can be seen in the average respondent responding well to each statement); this is also indicated by the largest average percentage score in each dimension in the good category where the percentage score is between $61 \%-80 \%$.

\section{Conclusion and Sugestion}

The norm calculation is also done to see the high, medium or low of each dimension of service quality and after the data has been processed with SPSS 16.00 for windows computers, it can be concluded that the overall response of 75 respondents to the level of quality of public services in Wonotirto District, Blitar Regency is good (can be seen in the average respondent responds well to each statement); this is also indicated by the largest average percentage score in each dimension in the good category where the percentage score is between $61 \%-80 \%$.

Some suggestions in the research on the quality of public services in Wonotirto Subdistrict, Blitar Regency, need to improve services by adding service facilities. such as efforts to add facilities and infrastructure (computers, printing machines, etc.). The Government of Wonotirto District can provide information to the public to deliver or provide a suggestion box to accommodate community aspirations. So, the employees can evaluate shortcomings and continue to improve the quality of services in the field of service in increasing satisfaction to the consumer. 


\section{References}

Huda, A. M., \& Martanti, D. E. (2018). Pengantar Manajemen Strategik 1. (J. Press, Ed.) (1st ed.). Bali:

http://books.jayapanguspress.org/index.php/publisher/article/view/18/18.

Nana Sudjana. 1997. CBSA Dalam Proses Belajar Mengajar. Jakarta: Rajawali Press.

Ndraha, Taliziduhu, 2000. Ilmu Pemerintahan (Kybernology), Jakarta: Rineka Cipta.

Peraturan Daerah No. 25 Tahun 2001 Tentang Retribusi Penyelenggaraan Pendaftaran dan Pencatatan Penduduk

Tjiptono, F.dan A. Diana. 2011. Total Quality Management Edisi Revisi, Andi: Yogyakarta 